\section{Measuring Ultrafine Particle \\ Concentrations at Salzburg \\ Airport: Using the Airport Closure due to Runway Reconstruction as a Natural Experiment}

Gl_Forum 2020, Issue 2

Page: 124 - 146

Full Paper

Corresponding Author: marcel.vorage@phsalzburg.at DOI: 10.1553/giscience2020_02_s124

\author{
Marcel Vorage1, Pierre Madl2, Alexander Kranabetter ${ }^{3}$ and Herbert Lettner2 \\ 'Salzburg University of Education Stefan Zweig, Austria \\ 2University of Salzburg, Austria \\ ${ }^{3}$ Federal State of Salzburg, Department of Immission Control, Austria
}

\begin{abstract}
During April and May 2019 Salzburg Airport was closed for five weeks for runway renovation. As a result, landings and take-offs (LTOS) were impossible during this period. This offered a rare opportunity to carry out a field study to investigate the concentration of ultrafine particles prior to, during and after completion of the renovation work. During the construction phase, the sharp particle concentration peaks resulting from LTOs during normal operation were no longer encountered at the measurement site, $140 \mathrm{~m}$ from the runway. Towards the end of the airport closure, construction activity was all but completed and LTO activity was strictly limited to test purposes, which resulted in average ultrafineparticle concentrations of approximately 3,000 to $4,000 \mathrm{~cm}^{-3}(06-23 \mathrm{~h}$ average value). The reconstruction work itself and the high numbers of construction vehicles caused an increase in ultrafine-particle concentrations of an additional 1,000 to $2,000 \mathrm{~cm}^{-3}(06-23 \mathrm{~h}$ average value). In comparison, in the three weeks before and the three weeks after the closure, when airport operations were running as normal, concentrations increased by 3,000 to $4,000 \mathrm{~cm}^{-3}$ (06-23 h average value).
\end{abstract}

\title{
Keywords:
}

ultrafine particles, particle number concentration, airport, natural experiment, construction site

\section{Introduction}

The reconstruction and closure of the runway at Salzburg Airport (SZG) during five weeks in April and May 2019 provided a unique opportunity to assess environmental effects of activities at the airport. Particles smaller than $100 \mathrm{~nm}$, so called ultrafine particles (UFP) or nanoparticles, were monitored before, during and after the closure. Every five seconds, the Condensation Particle Counter (CPC) counted the number of UFPs per $\mathrm{cm}^{3}$ at a carefully selected fixed location about $140 \mathrm{~m}$ from the runway. UFPs entering the measurement container cannot, unfortunately, be directly attributed to their source. In an attempt to counter 
this problem, this study estimates the effects of landing and take-off (LTO) as well as construction activity on levels and profiles of particle number concentrations in the weeks before, during and after the closure and reconstruction of the runway.

\section{UFP emissions from aircraft}

All turbofan and turboprop aircraft burn kerosene-type fuel and therefore emit UFPs. Particle concentrations immediately after exiting the aircraft's engine peak at around $15 \mathrm{~nm}$ in size in lower engine power conditions $(\leq 50 \%)$ and at around $40 \mathrm{~nm}$ for higher power conditions $(\geq 70 \%)$ (Kinsey, 2009). Particles are spatially mobile and change over time. After having travelled 100 to $300 \mathrm{~m}$ downwind, aircraft exhaust plumes contain a nucleation peak of particles that are mostly smaller than $10 \mathrm{~nm}$ with concentrations of about $10^{6} \mathrm{~cm}^{-3}$, and a condensation peak with particles around $80 \mathrm{~nm}$ with concentrations of about $10^{5} \mathrm{~cm}^{-3}$ (Herndon et al, 2008; Zhu et al, 2011; Lobo et al, 2012; Mazaheri et al, 2013; Timko et al, 2013; Lobo et al, 2015). Peak concentrations surpass $2 \cdot 10^{6} \mathrm{~cm}^{-3}$ at about $150 \mathrm{~m}$, and $3 \cdot 10^{5} \mathrm{~cm}^{-3}$ at up to $750 \mathrm{~m}$ from the runway at medium-sized commercial airports, compared to an urban background of $5 \cdot 10^{3} \mathrm{~cm}^{-3}$ to $5 \cdot 10^{4} \mathrm{~cm}^{-3}$ (Morawska et al, 2008; Press-Kristensen et al, 2012; Møller et al, 2014; Peters et al, 2016; Ren et al, 2016; Stafoggia et al, 2016; Vorage et al, 2019). Based on short-term variations in particle number concentrations, engine power settings of individual planes can be deduced during LTO activity (Vorage et al, 2019). When conventional kerosene is replaced by biofuel for aircraft propulsion, particle number concentrations can be reduced, but significant challenges remain and the use of biofuel remains limited in practice (Moore, et al, 2017; Wang et al, 2019). As aircraft are a source of noise and particle matter not only during LTO activities proper, the city of Salzburg along with the airport authority operates a permanent, spatially embedded, NoiseDesk ${ }^{\circledR}$ monitoring system (EMS Bruel \& Kjaer, Melbourne, Australia) that continuously allocates acoustic data to positions along the main flight routes from and towards the airport.

\section{UFP emissions from construction activities during runway closure}

Construction processes involving concrete generate UFPs. Impact demolition and recycling of dry materials cause a local increase in UFP concentrations by about $2 \cdot 10^{5} \mathrm{~cm}^{-3}$ (Kumar et al, 2012). In close proximity to the activity, cutting concrete results in concentrations that average more than $7 \cdot 10^{5} \mathrm{~cm}^{-3}$ and peak above $2 \cdot 10^{6} \mathrm{~cm}^{-3}$ (Azarmi et al, 2014). During certain phases of the abrasion and pouring of concrete, average and maximum concentrations surpass $1 \cdot 10^{5} \mathrm{~cm}^{-3}$ and $1 \cdot 10^{6} \mathrm{~cm}^{-3}$ respectively (Bujak-Pietrek and Mikołajczyk, 2019). These particles can indeed be caused by the construction activity itself, as UFPs with diameters of less than $30 \mathrm{~nm}$ can be created by mechanically fracturing concrete (Jabbour et al, 2017). Moreover, construction sites tend to involve the use of heavy vehicles. Clearly, diesel trucks emit UFPs as well (e.g. Zhu et al, 2002; Herner et al, 2007). As a result, some level of UFP emissions could be expected from multiple sources that were spatially linked to the runway reconstruction work.

\section{A poorly regulated health hazard}

UFPs are abundant in number but have small total mass. Because emissions regulation is historically built around limits on mass, UFP concentrations have remained largely unregulated. Unfortunately, this does not mean that they are harmless (see e.g. Gatti and Montanari, 2015). Airborne UFPs are capable of entering the body and circulating around the 
body. As a result of their small size, UFPs can enter the alveoli and pass through cell membranes while circumventing defence mechanisms like phagocytosis (Obersdörster et al, 2005; Bakand et al, 2012; Loane et al, 2013; Lu et al, 2015). Therefore, they can spread through lung tissues and organs such as the heart, liver, kidney and brain (Oberdörster et al, 2004; Kreyling et al, 2010; Yacobi et al, 2011) and even the central nervous system (Kleinman et al, 2008; Kreyling et al, 2013). While moving throughout the human body, UFPs can severely damage the immune and nervous systems, can cause inflammation, can negatively affect organ and cellular functions (e.g. mitochondrial activity), can damage DNA, and can pass to the foetal side of the placenta to pose a threat to the foetus during pregnancy (e.g. Bakand et al, 2012; Bové et al, 2019; Lu et al, 2015; Miller et al, 2017; Ulvestad, 2007). As UFPs are more abundant and collectively exhibit larger surface area than larger siblings, they interact with organic chemical structures relatively easily, especially inside the human body (Seinfeld and Pandis, 2016). It will come as no surprise, then, that increased exposure to UFPs is widely believed to reduce life expectancy (Hoek et al, 2010).

\section{Methodology}

\section{Sampling equipment}

Particle concentrations were measured using a condensation particle counter (CPC). CPCs employ a condensation principle whereby heated n-butyl-alcohol vapours are mixed with the nanometre-sized aerosol cloud. A condenser ensures that the supersaturated mixture provides rapid condensation onto the particle fraction. This has the effect of enlarging the aerosol sufficiently for a laser in the visible range to be used to screen the particles, to provide a clear signal.

A CPC of model 5421 (Grimm, Ainring, Germany) was used. This high-accuracy nanoparticle counter has a short response time allowing for reliable counting of concentrations up to $10^{7}$ particles $\mathrm{cm}^{-3}$. Particle concentrations were registered at five-second intervals, stored using specialized software, and exported into an Excel ${ }^{\circledR}$ spreadsheet. It should be noted that all CPCs have a range (smaller particle concentrations) in which each particle is counted individually, and another range (higher particle concentrations) in which this is no longer possible and concentrations are estimated photometrically using the Beer Lambert law. The switching point from individual to photometric measurements is at $1.5 \cdot 10^{5}$ particles $\mathrm{cm}^{-3}$. It is important to realize that although ultrafine particles can be counted using a CPC, they cannot directly be attributed to their source. Due to the design of the measurement container, the sampling hose inlet of the CPC 5421 is about $2 \mathrm{~m}$ long and has a diameter of $40 \mathrm{~mm}$. It therefore required an auxiliary pumping system $\left(60 \mathrm{~L} \mathrm{~min}^{-1}\right)$ to route the sampling air through the chimney towards the extracting slot for the sampling instrument, at a flow rate of 1.2 $\mathrm{L} \mathrm{min}^{-1}$. The temperature in the measurement containers housing these instruments was maintained at $20^{\circ} \mathrm{C}$ to $24^{\circ} \mathrm{C}$. Detailed information on the sampling equipment, including schematic representations, can be found in the Appendix, 'Operating principles of aerosol particle counting', at the end of this paper. 


\section{Sampling site}

Salzburg airport (SZG) is located about $3 \mathrm{~km}$ to the southwest of the city centre, adjacent to highway A1. The Innsbrucker Bundesstrasse (local road B1) passes under the runway via a tunnel (see Figure 1). SZG has a single runway in direction $15 / 33 \mathrm{NS}$ (or $150^{\circ} / 330^{\circ}$ ) with a length of $2750 \mathrm{~m}$, a stop-way of $100 \mathrm{~m}$ and a width of $45 \mathrm{~m}$. The direction of the runway enables aircraft to take off and land against the prevailing winds (see Figure 2). SZG is comparatively small, with 18,457 landings and take-offs by commercial airlines in 2018 (Salzburg Airport, 2020). In addition, a large number of private flights are undertaken at SZG, with private landings and take-offs totalling 36,759 in 2016 (Vorage et al., 2019). The fixed sampling site was located approximately $140 \mathrm{~m}$ to the southeast of the runway. The site was carefully chosen as the better of two possible locations, one on each side of the runway, based on a previous investigation (Vorage et al, 2019). The site had to satisfy two important requirements: i) the air-conditioned measurement container is fitted with various high-tech instruments requiring a reliable high-capacity power supply; ii) for safety reasons and to minimize potential acts of vandalism, it is operated from inside a fenced area. Other locations considered were not close enough to the runway, and because the runway operates in both directions $\left(150^{\circ}\right.$ to $330^{\circ}$ or $330^{\circ}$ to $\left.150^{\circ}\right)$ they would not have allowed appropriate monitoring of spatially distributed exhaust aerosols.

\section{Airport development and runway reconstruction}

The airport was opened at its current location in 1926, since when it has been expanded and modernized multiple times. A significant extension of the runway was undertaken in the 1960s. A second terminal building was added in 2003 to be able to better handle peak traffic during the winter holiday season. The runway at SZG was reconstructed in April and May 2019, leading to the airport's closure for five weeks from 24.04.2019 to 28.05.2019 (Salzburg Airport, 2019).

\section{Noise Desk data and LTO activity}

The flight routes for each individual flight at SZG can be combined into a single map using the permanent spatial NoiseDesk ${ }^{\circledR}$ monitoring system (EMS Bruel \& Kjaer, Melbourne, Australia). Such a map was plotted for three individual 24-hour periods of flight movements (from $0 \mathrm{~h}$ in the morning to $24 \mathrm{~h}$ (midnight)). The three days shown here represent typical days before, during and after the airport closure for reconstruction: 24.04.2019 (Figure 3a; before closure), 15.05.2019 (Figure 3b; during closure) and 30.05.2019 (Figure 3c; after reopening). The closure of the airport inhibited any form of LTO activity, reducing associated UFP emissions to almost zero, while the nearby heliport was still in operation (see Figure 3b), generating some aircraft-related exhaust aerosols.

\section{Construction activity and UFPs}

The absence of airplane-related LTO activity does not imply a complete absence of ultrafine particles coming from the airport site. For example, approximately $115 \mathrm{kt}$ of asphalt in four layers were needed for the top cover of the $45 \mathrm{~m}$ wide, $2850 \mathrm{~m}$ long runway, which was supplied by a constant flow of trucks (on average one every three mins). This four-layered stratum is porous enough to facilitate rapid rainwater draining, which makes runway grooving and the associated generation of dust obsolete (Agrawal \& Daiutolo, 1985). The increase in particle concentration of 1,000 to $2,000 \mathrm{~cm}^{-3}(06-23 \mathrm{~h}$ mean value) as observed at the measurement site was attributed to high material turnover and the use of heavy machinery, 
which was limited to 06:00-22:00. Only low-level noise-generating tasks (electrical wiring, installation of above-ground lighting sources, etc.) took place during the night hours, these same activities also being less generative of UFPs.

\section{Limitations and study design}

UFPs are very small, with a diameter up to $100 \mathrm{~nm}$. They can be counted using elaborate and expensive technical equipment, but cannot be traced back to their source. Using a single carefully positioned, stationary measurement container (Vorage et al, 2019), particle concentrations were measured every five seconds in the weeks before, during and after the airport closure. The measurement container was located immediately outside the airport's safety perimeter. In this way, UFPs were counted as close as possible to normal LTO and construction activity. Nevertheless, because of the particles' small size, wind may carry UFPs towards or away from the measurement container. Therefore, the direction and speed of prevailing winds were taken into account when interpreting particle concentrations. This setup was chosen in order to obtain a more reliable estimate of the effects of LTO activity, as well as of the effects of different phases of the reconstruction process on particle concentrations at SZG.

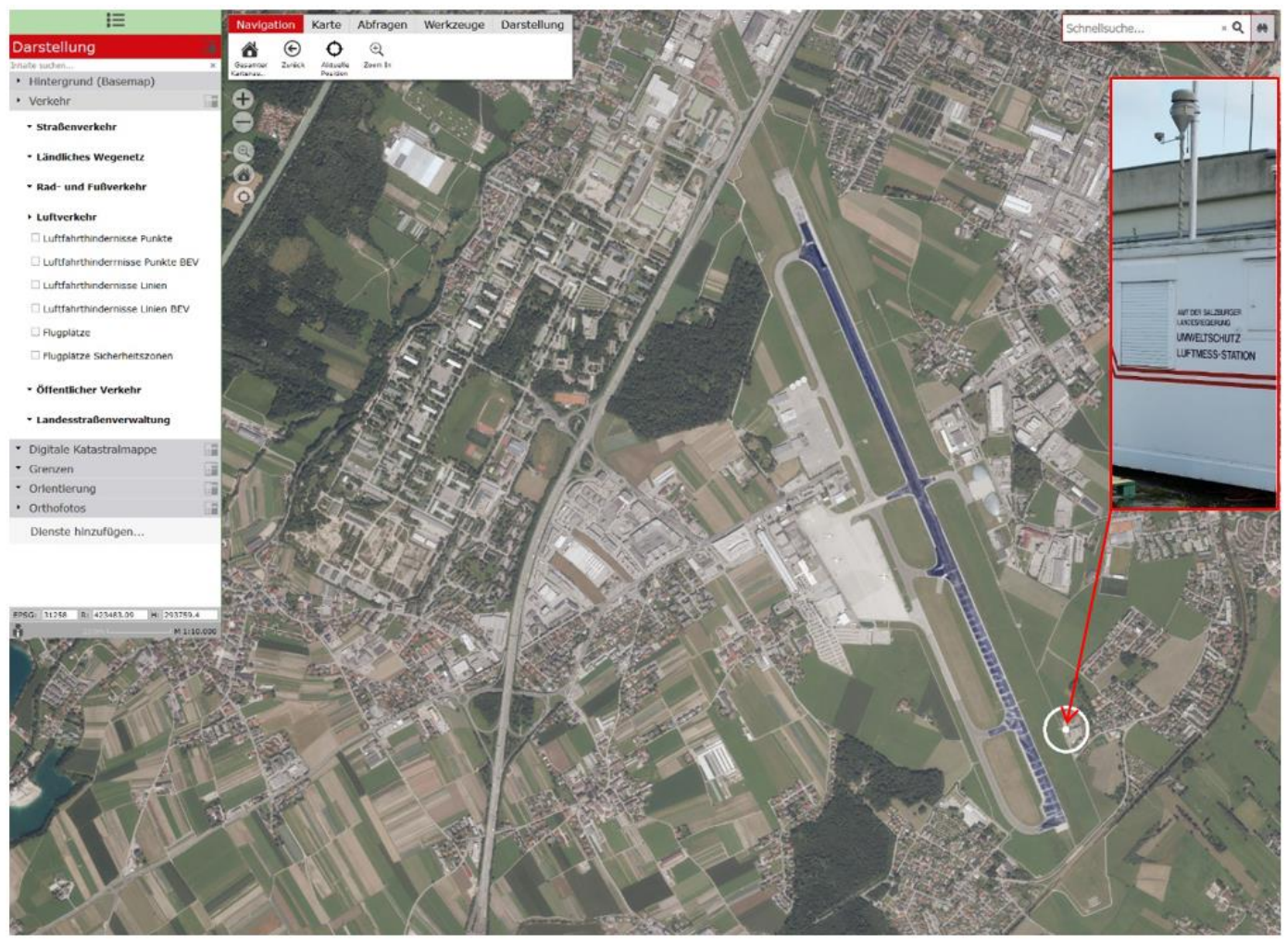

Figure 1: Satellite picture of Salzburg Airport during the reconstruction of the runway with sampling site (O) to the southeast of the runway (SAGIS Maps, accessed on 11 October 2019). When the wind was blowing from $170^{\circ}$ to $335^{\circ}$, particles resulting from activities on the runway could be registered at the sampling site. 


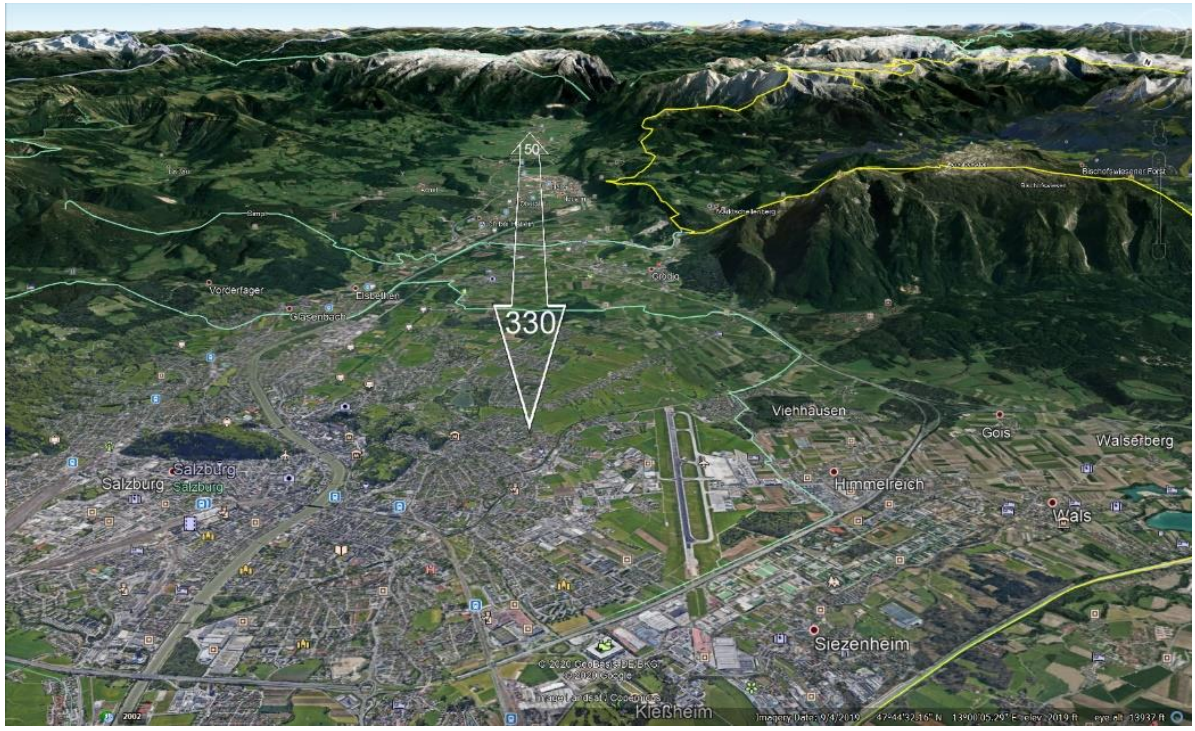

Figure 2: Simulated 3D-perspective in the direction $150^{\circ}$, showing the runway at SZG (accessed on 16 April 2020). Prevailing winds blow in both directions through the Salzach Valley, as shown by the superimposed arrow (modified Google Earth image).

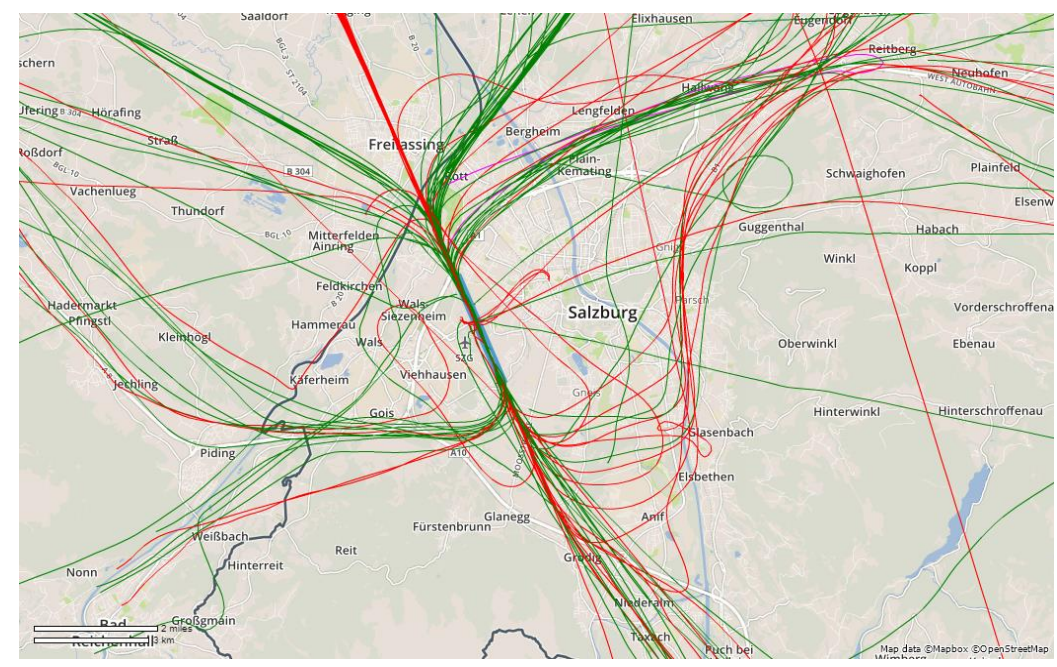

Figure 3a: LTO activity at SZG on 24.04.2019 (OpenStreetMap), monitored via the NoiseDesk® datagathering system coupled to permanently installed sensor stations. Inbound flights in red, outbound flights in green highlight the wider airport neighbourhood subject to airplane-based aerosol exposure. 


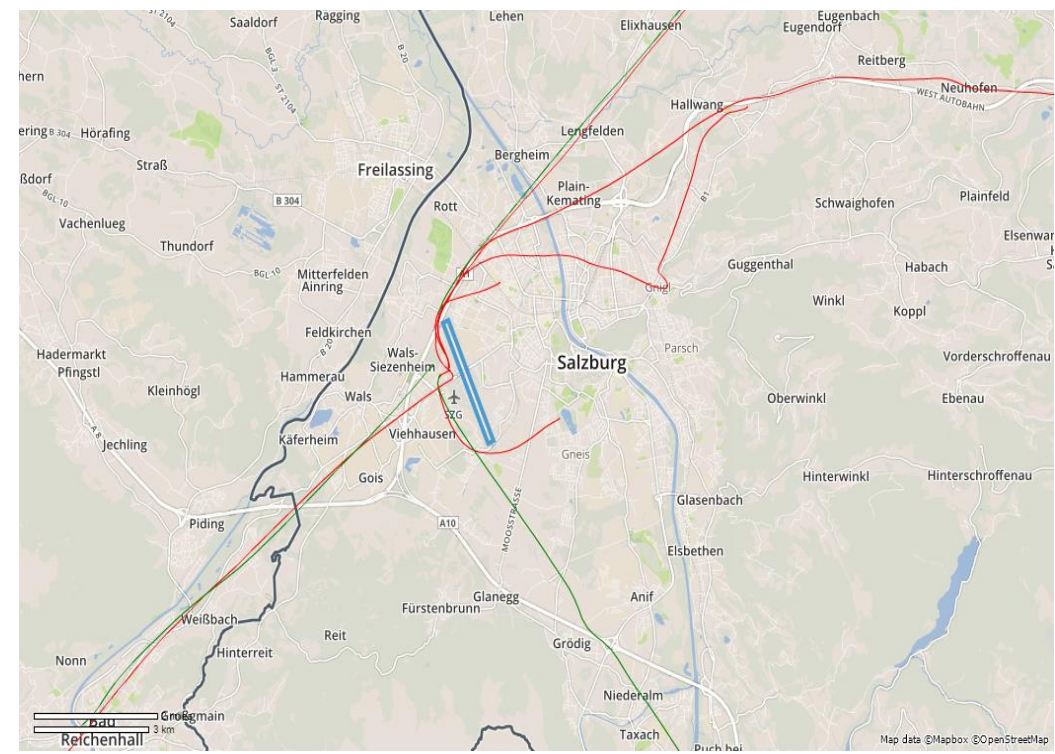

Figure 3b: LTO activity at SZG on 15.05.2019 (OpenStreetMap), monitored via the NoiseDesk® datagathering system coupled to permanently installed sensor stations. Inbound flights in red, outbound flights in green. The presence of flight data during runway closure relates to helicopter activity at the nearby heliport, which explains the irregular shapes of the flight routes.

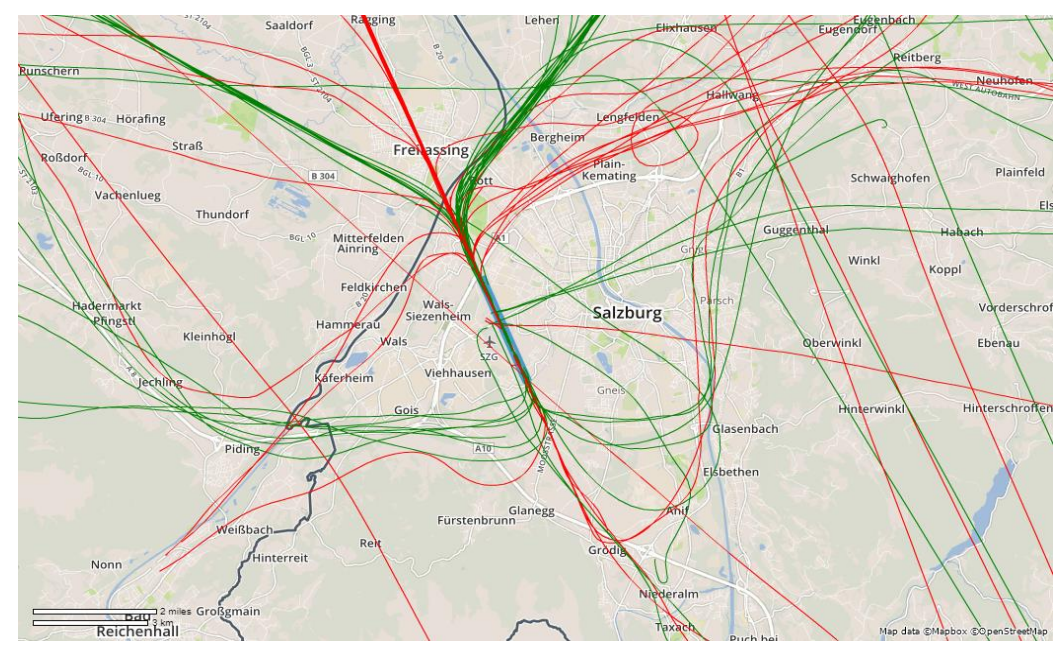

Figure 3c: LTO activity at SZG on 30.05.2019 (OpenStreetMap), monitored via the NoiseDesk® datagathering system coupled to permanently installed sensor stations. Inbound flights in red, outbound flights in green highlight the wider airport neighbourhood subject to airplane-based aerosol exposure.

\section{Satellite images of airport reconstruction}

The reconstruction of the runway at SZG was captured by satellite images, some of which are presented here. Due to the length of the runway and the tight schedule for completing the work, different kinds of activity took place simultaneously at different locations. 


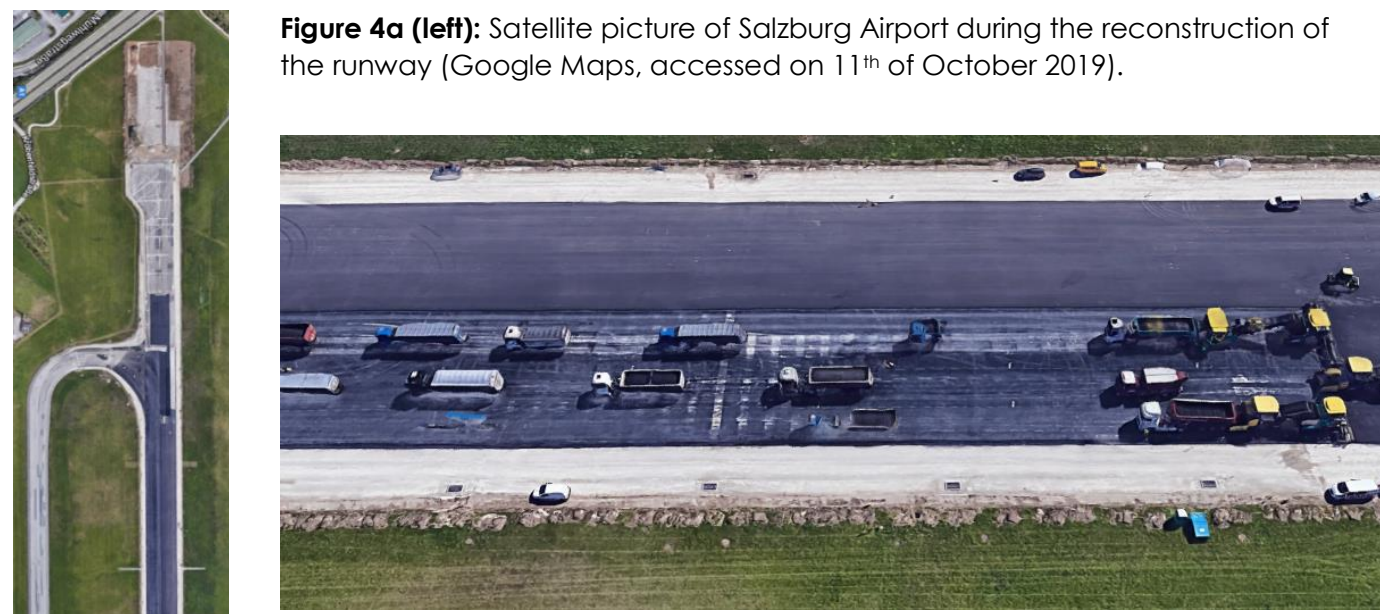

Figure 4b: Satellite picture of work on the runway's bitumen layer (Google Maps, accessed on the $11^{\text {th }}$ of October 2019).

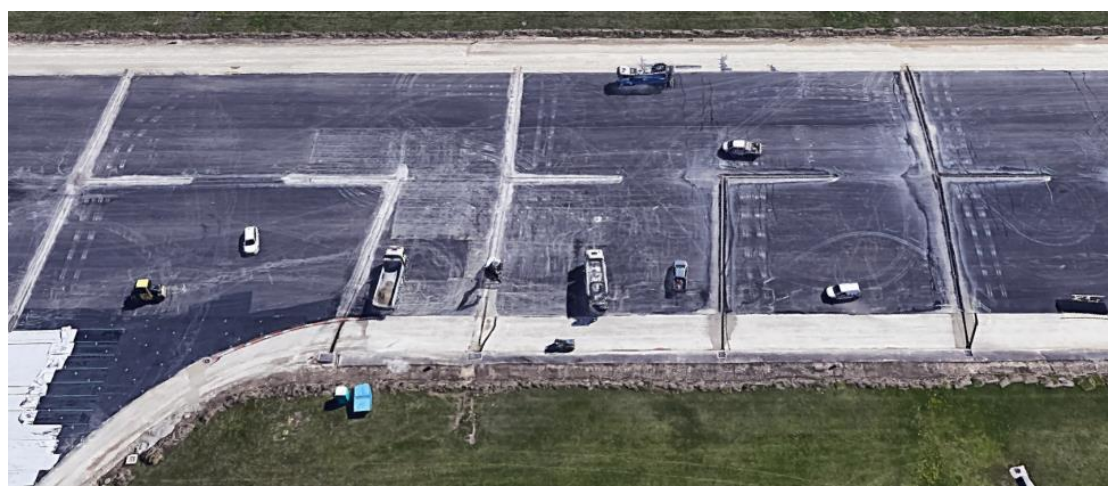

Figure 4c: Satellite picture of work on the runway's drainage system (Google Maps, accessed on the $11^{\text {th }}$ of October 2019).

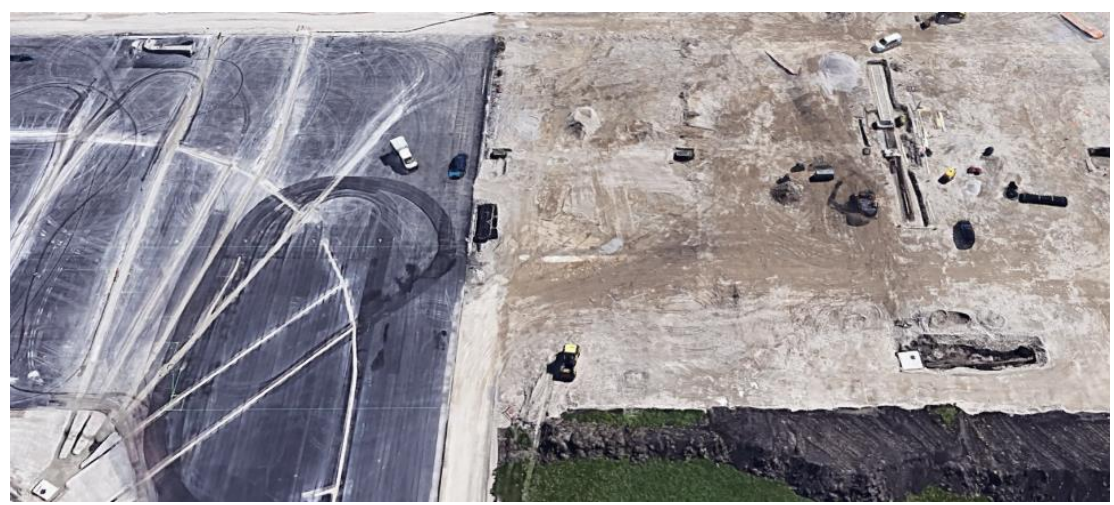

Figure 4d: Satellite picture of work on the south-eastern end of the runway (Google Maps, accessed on $11^{\text {th }}$ October 2019). 


\section{Results}

SZG operates daily from $6 \mathrm{~h}$ to $23 \mathrm{~h}$. The construction site was operational from $6 \mathrm{~h}$ to $22 \mathrm{~h}$. To allow comparison between periods of normal airport operation and runway reconstruction, data from $6 \mathrm{~h}$ until $23 \mathrm{~h}$ is represented in the summary statistics consistently. The entire period of analysis runs from 03.04.2019 until 18.06.2019. It includes three weeks both before and after the five-week runway reconstruction period.

The CPC was permanently located at the sampling site and continuously measured particle concentrations at five-second intervals. Short interruptions occurred during pre-construction (04.04.2019: $10: 06: 25$ to $10: 38: 25 ; 23.04 .2019$ : $13: 34: 35$ to $13: 40: 55)$, during construction (25.04.2019: 8:22:35 to $8: 23: 00 ; 27.04 .2019$ : $07: 02: 55$ to $07: 03: 00 ; 07.05 .2019: 13: 21: 15$ to 13:21:20; 10.05.2019: 07:10:35 to $07: 10: 40$ \& $07: 29: 05$ to $07: 29: 10 ; 14.05 .2019: 08: 07: 05$ to 9:19:55), as well as during post-construction (03.06.2019: 06:02:50 to 06:03:00; 17.06.2019: at 22:04:25 only).

Table A: Summary of statistics of particle numbers at five-second intervals between 06:00:00 and 23:00:00 for the three-week period before, the five-week period during, and the three-week period after construction.

\begin{tabular}{|c|c|c|c|c|c|c|c|}
\hline Aerosol counts & $\begin{array}{l}\text { Sample } \\
\text { size } \\
(n)\end{array}$ & $\begin{array}{l}\text { Average } \\
\left(\mathrm{cm}^{-3}\right)\end{array}$ & $\begin{array}{l}\text { Median } \\
\left(\mathrm{cm}^{-3}\right)\end{array}$ & $\begin{array}{l}\text { Minimum } \\
\left(\mathrm{cm}^{-3}\right)\end{array}$ & $\begin{array}{l}\text { Maximum } \\
\left(\mathrm{cm}^{-3}\right)\end{array}$ & $\begin{array}{l}\text { Standard } \\
\text { Deviation } \\
\left(\mathrm{cm}^{-3}\right)\end{array}$ & $\begin{array}{l}\text { Wind to } \\
\text { CPC } \\
\text { (\% time) }\end{array}$ \\
\hline $\begin{array}{l}\text { Three-week } \\
\text { period before } \\
\text { construction } \\
03.04 .2019 \text { - } \\
23.04 .2019\end{array}$ & 256,863 & 6,665 & 4,274 & 393 & 285,700 & 9,982 & 32.24 \\
\hline $\begin{array}{l}\text { Five-week } \\
\text { period during } \\
\text { construction } \\
24.04 .2019 \text { - } \\
28.05 .2019\end{array}$ & 427,804 & 4,548 & 3,440 & 461 & $2,173,000$ & 8,386 & 50.12 \\
\hline $\begin{array}{l}\text { Three-week } \\
\text { period after } \\
\text { construction } \\
29.05 .2019 \text { - } \\
18.06 .2019\end{array}$ & 257,756 & 7,251 & 5,180 & 950 & 258,900 & 10,803 & 41.36 \\
\hline
\end{tabular}


Table B: Overview of wind speeds towards the sampling site measured at half-hourly intervals between 06:00:00 and 23:00:00 for the three-week period before, the five-week period during, and the threeweek period after construction. Wind speeds are given in metres per second $\left(\mathrm{m} \mathrm{s}^{-1}\right)$.

\begin{tabular}{|l|l|l|l|l|l|l|l|}
\hline \multirow{2}{*}{$\begin{array}{l}\text { Wind } \\
\text { direction and } \\
\text { speed }\end{array}$} & \multicolumn{4}{|l|}{ Wind towards CPC $\left(170^{\circ}-335^{\circ}\right)$} & Other \\
\cline { 2 - 8 } & $0-1 \mathrm{~m} \mathrm{~s}^{-1}$ & $1-2 \mathrm{~m} \mathrm{~s}^{-1}$ & $2-4 \mathrm{~m} \mathrm{~s}^{-1}$ & $4-6 \mathrm{~m} \mathrm{~s}^{-1}$ & $6-8 \mathrm{~m} \mathrm{~s}^{-1}$ & $8-12 \mathrm{~m} \mathrm{~s}^{-1}$ & $\begin{array}{l}\text { dir- } \\
\text { ections } \\
(\%)\end{array}$ \\
\hline $\begin{array}{l}\text { Three-week } \\
\text { period before } \\
\text { construction } \\
\text { 03.04.2019- } \\
\text { 23.04.2019 }\end{array}$ & 6.94 & 12.11 & 11.84 & 0.95 & 0.00 & 0.41 & 67.76 \\
\hline $\begin{array}{l}\text { Five-week } \\
\text { period during } \\
\text { construction } \\
\begin{array}{l}24.04 .2019- \\
\text { 28.05.2019 }\end{array}\end{array}$ & 4.16 & 13.96 & 21.71 & 8.41 & 0.82 & 1.06 & 49.88 \\
\hline $\begin{array}{l}\text { Three-week } \\
\text { period after } \\
\text { construction } \\
\text { 29.05.2019 - } \\
\text { 18.06.2019 }\end{array}$ & 2.45 & 13.20 & 17.41 & 5.71 & 1.63 & 0.95 & 58.64 \\
\hline
\end{tabular}

Average and median particle concentrations were much lower during construction compared to those during airport operation before or after construction. Winds that increase the spatial mobility of UFPs towards the sampling site were more prevalent during construction, with winds speeds mostly ranging from 1 to 6 metres per second $\left(\mathrm{m} \mathrm{s}^{-1}\right)$, implying that the difference may be even larger than shown here. In addition to wind direction and wind speed, further meteorological conditions should be considered. Prior to the runway closure, the month of April was relatively mild and largely dry. The month of May, when the bulk of the reconstruction activity took place, was the coolest May for the last 200 years and experienced above-average rainfall. The period was characterized by unstable weather and good air mixing, which resulted in below-average pollutant concentrations at a reference site within the city of Salzburg that captures emissions from road traffic. In particular, the level of particles with a diameter of $10 \mu \mathrm{m}$ or less $\left(\mathrm{PM}_{10}\right)$ and $2.5 \mu \mathrm{m}$ or less $\left(\mathrm{PM}_{2.5}\right)$ were low compared to the May measurements of previous years (Kranabetter, 2019). After SZG was re-opened to air traffic, June was one of the warmest Junes on record for the last 200 years, with above-average sunshine and below-average precipitation.

In line with the presence of short-lived peaks associated with LTO activity during airport operation, the standard deviation and the difference between average and median particle concentrations were lower during the construction period. Interestingly, the highest particle concentrations were registered during two events of the runway restoration: one was attributable to the asphalting work (which is always associated with high hydrocarbon emissions); unfortunately, we are unable to retrospectively deduce what source caused the other maximum. 
Table C: Summary of statistics for particle numbers at five-second intervals between 06:00:00 and 23:00:00 for the different construction phases (Salzburg Airport, 2019). Note that some of the phases overlap due to the length of the runway and the tight schedule for the runway reconstruction.

\begin{tabular}{|c|c|c|c|c|c|c|}
\hline $\begin{array}{l}\text { Aerosol counts } \\
\text { during } \\
\text { Construction } \\
\text { (sub)phases }\end{array}$ & $\begin{array}{l}\text { Sample } \\
\text { size } \\
(n)\end{array}$ & $\begin{array}{l}\text { Average } \\
\left(\mathrm{cm}^{-3}\right)\end{array}$ & $\begin{array}{l}\text { Median } \\
\left(\mathrm{cm}^{-3}\right)\end{array}$ & $\begin{array}{l}\text { Minimum } \\
\left(\mathrm{cm}^{-3}\right)\end{array}$ & $\begin{array}{l}\text { Maximum } \\
\left(\mathrm{cm}^{-3}\right)\end{array}$ & $\begin{array}{l}\text { Standard } \\
\text { deviation } \\
\left(\mathrm{cm}^{-3}\right)\end{array}$ \\
\hline $\begin{array}{l}\text { Installing four- } \\
\text { layer asphalt } \\
\text { stratum } \\
24.04 .2019 \text { - } \\
18.05 .2019\end{array}$ & 305,404 & 4,837 & 3,461 & 483 & $2,173,000$ & 9,765 \\
\hline $\begin{array}{l}\text { Drilling and } \\
\text { cabling for LED- } \\
\text { lighting, removing } \\
\text { upper bitumen } \\
\text { layer } \\
12.05 .2019 \text { - } \\
15.05 .2019\end{array}$ & 48,378 & 4,953 & 3,494 & 483 & 744,100 & 11,082 \\
\hline $\begin{array}{l}\text { Installing } \\
\text { markings and } \\
\text { borders, } \\
\text { landscaping } \\
13.05 .2019 \text { - } \\
22.05 .2019\end{array}$ & 121,818 & 4,809 & 3,556 & 461 & $2,173,000$ & 13,661 \\
\hline $\begin{array}{l}\text { Testing and } \\
\text { finalizing site } \\
\text { before usage } \\
22.05 .2018- \\
28.05 .2019\end{array}$ & 85,680 & 3,819 & 3,283 & 1,234 & 196,500 & 2,571 \\
\hline $\begin{array}{l}\text { Official approval, } \\
\text { test flights, re- } \\
\text { establishing } \\
\text { security perimeter } \\
27.05 .2019 \text { - } \\
28.05 .2019\end{array}$ & 24,480 & 3,540 & 3,159 & 1,234 & 196,500 & 3,235 \\
\hline
\end{tabular}


Table D: Overview of wind speeds towards the sampling site measured at half-hourly intervals between 06:00:00 and 23:00:00 for the four-week reconstruction period and the single week of testing and finalizing the runway. The official project description allocates 22.05 .2019 to both project phases (Salzburg Airport, 2019). Wind speeds are given in metres per second ( $\mathrm{m} \mathrm{s}^{-1}$ ).

\begin{tabular}{|c|c|c|c|c|c|c|c|}
\hline \multirow[b]{2}{*}{$\begin{array}{l}\text { Wind } \\
\text { direction } \\
\text { during } \\
\text { construction }\end{array}$} & \multicolumn{6}{|c|}{ Wind towards CPC $\left(170^{\circ}-335^{\circ}\right)$} & \multirow{2}{*}{$\begin{array}{l}\text { Other } \\
\text { dir- } \\
\text { ections } \\
(\%)\end{array}$} \\
\hline & $\begin{array}{l}0-1 \mathrm{~m} \mathrm{~s}^{-1} \\
(\%)\end{array}$ & $\begin{array}{l}1-2 \mathrm{~m} \mathrm{~s}^{-1} \\
(\%)\end{array}$ & $\begin{array}{l}2-4 \mathrm{~m} \mathrm{~s}^{-1} \\
(\%)\end{array}$ & $\begin{array}{l}4-6 \mathrm{~m} \mathrm{~s}^{-1} \\
(\%)\end{array}$ & $\begin{array}{l}6-8 \mathrm{~m} \mathrm{~s}^{-1} \\
(\%)\end{array}$ & $\begin{array}{l}8-12 \mathrm{~m} \mathrm{~s}^{-1} \\
(\%)\end{array}$ & \\
\hline $\begin{array}{l}\text { Runway re- } \\
\text { construction } \\
24.04 .2019 \text { - } \\
22.05 .2019\end{array}$ & 3.84 & 12.71 & 20.30 & 9.46 & 0.99 & 1.28 & 51.43 \\
\hline $\begin{array}{l}\text { Testing and } \\
\text { finalizing } \\
22.05 .2019- \\
28.05 .2019\end{array}$ & 5.31 & 21.63 & 31.43 & 2.86 & 0.00 & 0.00 & 38.78 \\
\hline
\end{tabular}

Particle concentrations were higher during runway reconstruction from 24.04.2019 to 22.05.2019 than during testing and finalization (22.05.2020 to 28.05.2020). A higher prevalence of winds blowing towards the test site in the latter phase implies an underestimation of this difference (see Table D). Construction work involves the removal of existing runway infrastructure, drilling, landscaping, etc., with the accompanying movement of construction vehicles and up to 300 lorry-loads of construction materials having to be transported per day. These activities generate significant particle matter. Finalizing the runway, testing it and obtaining official approval do not require movements of significant numbers of vehicles. On the other hand, test flights result in sporadic short-lived peaks with high particle concentrations. If we compare the last week of airport closure to the four weeks of reconstruction preceding it, we see that construction activity increases UFP concentrations by an estimated 1,000 to $2,000 \mathrm{~cm}^{-3}$ on average. In a similar fashion, comparing UFP concentrations during the last week of the airport closure with the concentrations during normal airport operations offers the best opportunity to estimate the particle contributions of LTO activity at 3,000 to $4,000 \mathrm{~cm}^{-3}$ on average. Both estimates are likely to be on the conservative side, because most often the wind was blowing towards the sampling site during the period of testing and finalizing the site, which was used as a base-line because particle concentrations were at the lowest level (construction is completed and LTO activity remains limited to very few test flights at most).

To obtain further insights into the effects of the airport closure and runway reconstruction on particle concentrations, observe the particle concentration profiles during the week that included the closure of the airport (Figure 5), and the week during which the airport re-opened (Figure 6). 


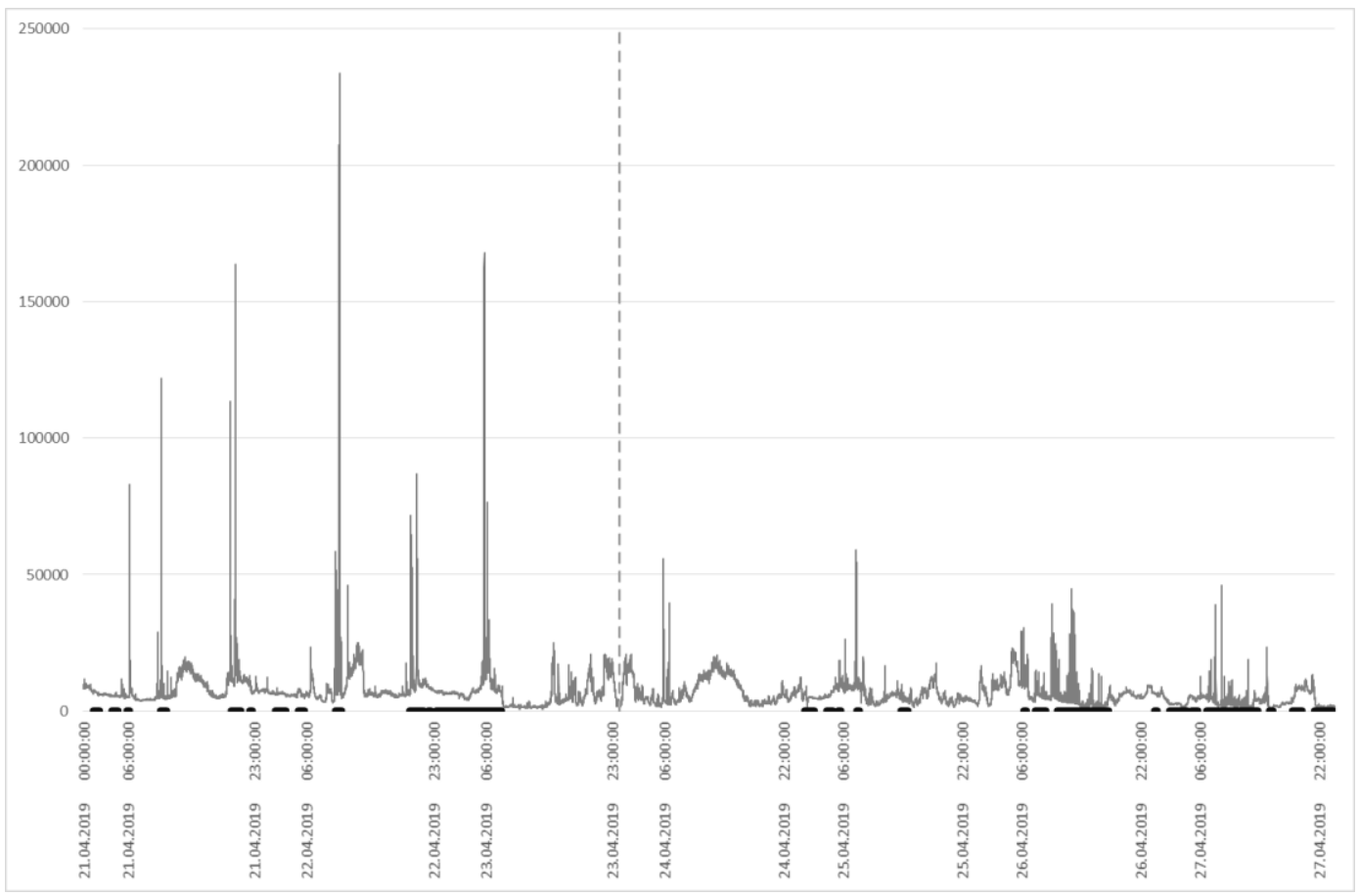

Figure 5: Particle numbers registered at the sampling site from 00:00:00 on 21.04.2019 to 24:00:00 on 27.04.2019. The runway was closed for reconstruction at 00:00:00 on 24.04.2019 (dashed line). Before the closure, the airport operated daily from 06:00:00 until 23:00:00. After the closure, the construction site was active daily from 06:00:00 until 22:00:00. During the periods marked by the black line at the bottom of the graph, the wind was blowing in the direction of the sampling site $\left(170^{\circ}-335^{\circ}\right)$.

Short-lived peaks in particle numbers typically associated with aircraft activities are clearly visible during airport operating times before the closure. These only occur when the wind is blowing from the runway towards the sampling site. After the closure of the runway, no such peaks are seen, even during winds towards the sampling site. Construction activity leads to particle concentrations of above $50,000 \mathrm{~cm}^{-3}$. These are higher concentrations than can be attributed to flows of commuter traffic on roads A1 and B1 (see Figure 5). This is corroborated by particle concentrations just before the reopening of the airport. Even with winds towards the sampling site, particle concentrations tend to stay below $10,000 \mathrm{~cm}^{-3}$. During the two days before the reopening, four or five sharp spikes can be distinguished. Given their shape, it is very likely that these were caused by test flights. After the reopening of the airport, the number of LTO-related spikes increases dramatically during winds towards the sampling site. A few such spikes even occur without the proven presence of such winds, which were measured only at half-hourly intervals (see Figure 6). Throughout the night, particle concentrations are low, no matter the wind or the operationality of the airport. 


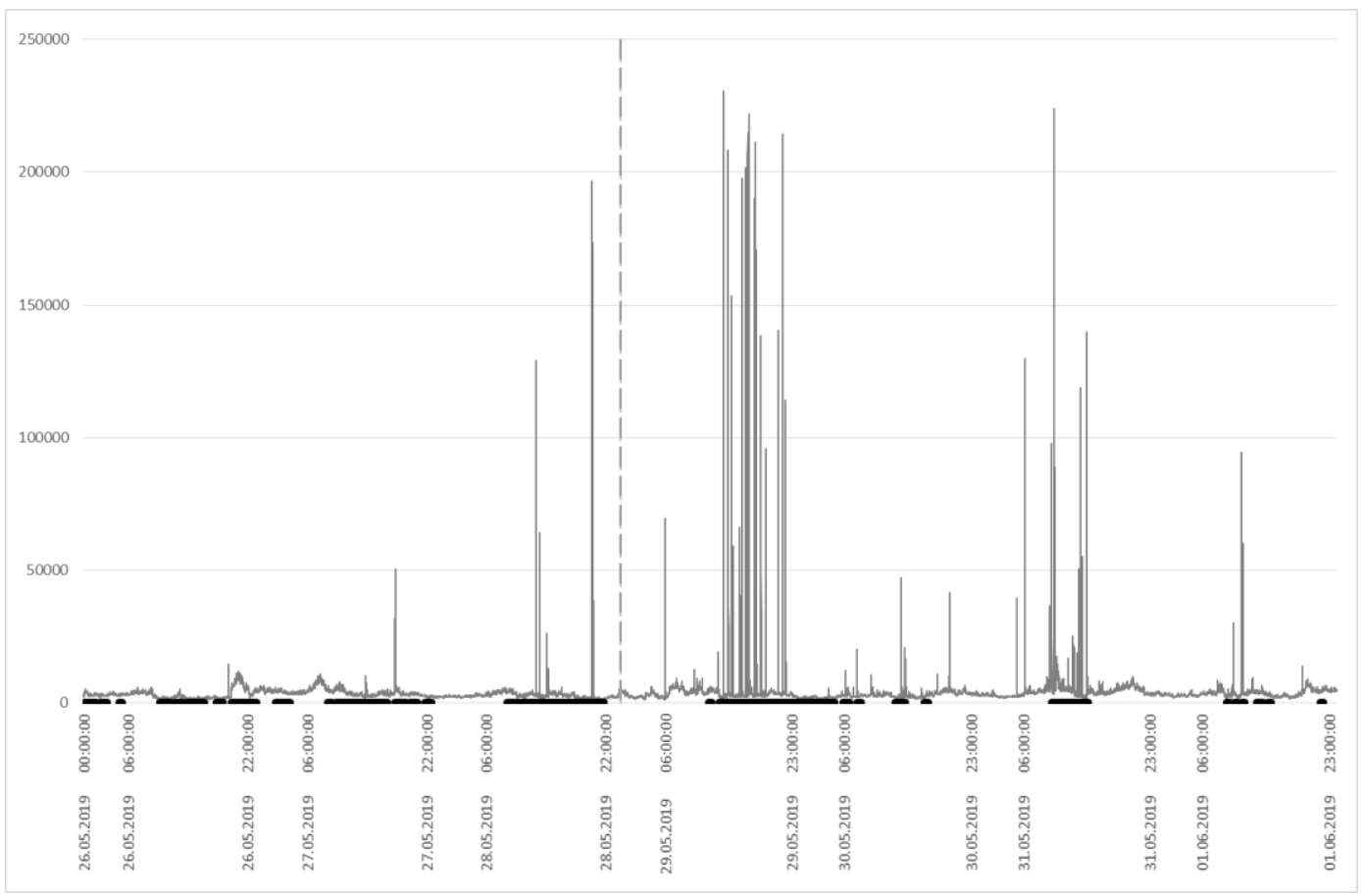

Figure 6: Particle numbers registered at the sampling site from 00:00:00 on 26.05.2019 to 24:00:00 on 01.06.2019. The runway was reopened at 00:00:00 on 28.05.2019 (dashed line). Before reopening, the construction site was active daily from 06:00:00 to 22:00:00. After reopening, the airport operated daily from 06:00:00 to 23:00:00. During the periods marked by the black line at the bottom of the graph, the wind was blowing in the direction of the sampling site $\left(170^{\circ}-335^{\circ}\right)$.

\section{Conclusion}

The closure of the runway at Salzburg Airport (SZG) for reconstruction during spring 2019 created a unique opportunity to evaluate the differences in numbers of airborne particles between no-flight conditions and normal LTO activities. Despite the comparatively small number of landings and take-offs at SZG, the measurements in this study suggest an air-traffic related impact that amounts to an average of 3,000 to 4,000 particles $\mathrm{cm}^{-3}$ during airport operations at our sampling site, about $140 \mathrm{~m}$ from the runway. The typical short-lived peaks associated with LTO activity disappeared during the construction work, other than for a few test flights shortly before the airport was reopened. Aircraft emissions are not geographically limited to LTO activity at the airport itself; they persist over the approach and take-off flight routes at SZG. The measurements were conducted at a single location at ground level and are not readily transferrable to large geographical areas due to the three-dimensional movement of the particle sources (i.e. aircraft) and complicated particle dynamics over space and time. Construction activity increased concentrations by about 1,000 to $2,000 \mathrm{~cm}^{-3}$, as measured at the same location. Both estimates are expected to be on the conservative side due to the prevailing winds during our measurements, which greatly affect the spatial distribution of the 
exhaust plume. Moreover, LTO activity at SZG tends to be significantly lower in spring than in winter, the latter being related to the peak skiing season.

In the context of the current debate around emissions and climate change in relation to aircraft and construction sites, these findings add new information to help improve decision-making processes. The findings are particularly important in light of the lack of regulation surrounding UFPs. The current gravimetric limits are not effective in regulating them, because UFPs are large in number and small in mass. Such regulations are designed for use at European level, but foremost for road traffic-related exhaust (e.g. EuroLex, 2019). Aviation emissions are currently being assessed as part of the EU's H2020 research programme (Aviator, 2020). If regulatory limits prove to be difficult to impose, a legal framework for active measurement could at least be put in place. To improve local knowledge and decision making, we recommend extending fixed air-monitoring stations to include UFP counters, such as the one at $S Z G$, at all airports.

During airport operation, landing fees could reflect the (expected) effects of specific LTO activity on air quality, as different types of aircraft and fuel as well as engine settings generate different emissions (Kinsey, 2009; Moore et al, 2017). Because wind speed and direction affect the distribution of the emission plume (Vorage et al, 2019) and weather conditions affect particle dynamics (especially during winter by facilitating the formation of inversion layers and increased particle number concentrations at ground level; Janhäll et al. (2006)), LTO-related emissions for a given aircraft can be deduced by statistical inference. In the longer term, the number of scheduled flights of a specific aircraft type (and engine) would yield a dataset that could provide an airplane-specific emission factor and its landing-fee category.

During airport (re)construction, further measures could be taken to limit the impact of UFPs. Trucking routes could be adapted to reduce local residents' or workers' exposure to UFPs. Air inlets of airport ventilation systems should include modern, well-serviced filter systems (Stephens and Siegel, 2013) because outside air is used for ventilation (Morawska et al., 2009; Quang et al., 2013). Although further measurements would be needed to determine the optimal setup, ventilation inlets could potentially be positioned at locations that exhibit relatively low particle numbers. Moreover, ventilation systems could include air-monitoring to actively adjust the mixing of inside and outside air, as well as to take air from a variety of inlets. This could be particularly effective in an airport setting, given that UFP concentrations at airports fluctuate heavily in relation to LTO activity.

\section{Appendix}

The next few pages will briefly highlight the basic components for accurate and reproducible aerosol-counting under fluctuating meteorological outdoor conditions. The entire sampling line, consisting of sampling pipe and Condensation Particle Counter (CPC) along with other environmental monitoring systems, is housed in an air-conditioned container (see Figure 7), which is kept at a constant temperature of $20^{\circ} \mathrm{C}$ throughout the measurement campaign. 


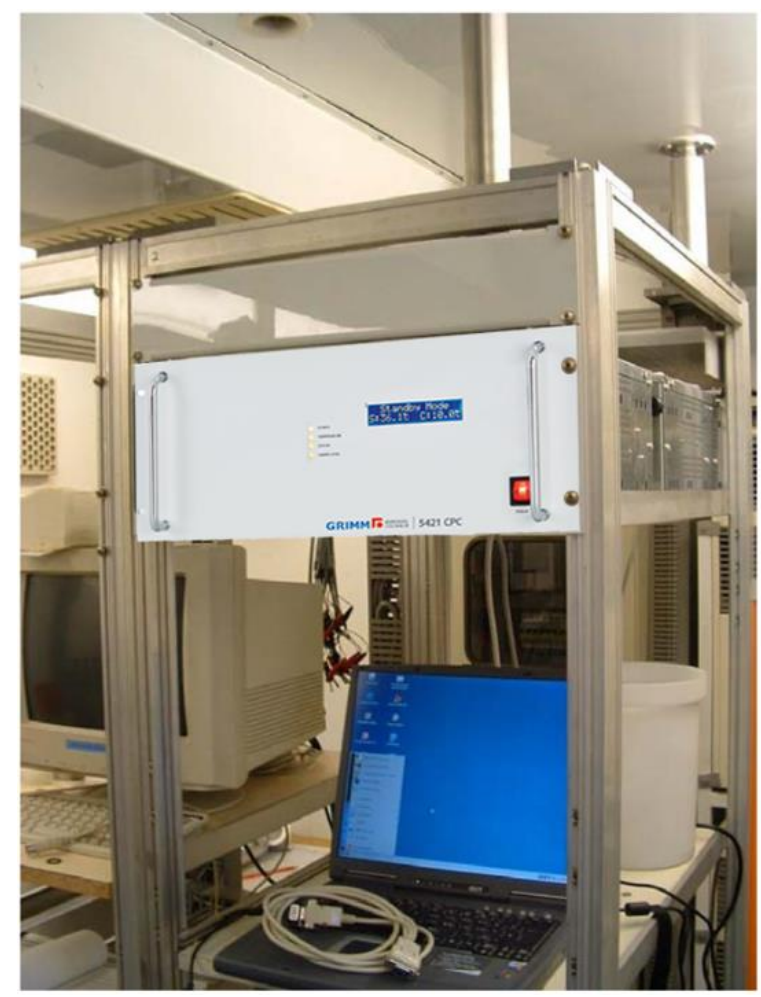

Figure 7:

Setup of the aerosol measurement unit within the air-conditioned container, showing the CPC-5421 unit with the attached sampling pipe and data processing unit.

\section{Dehumidification (Permature stage)}

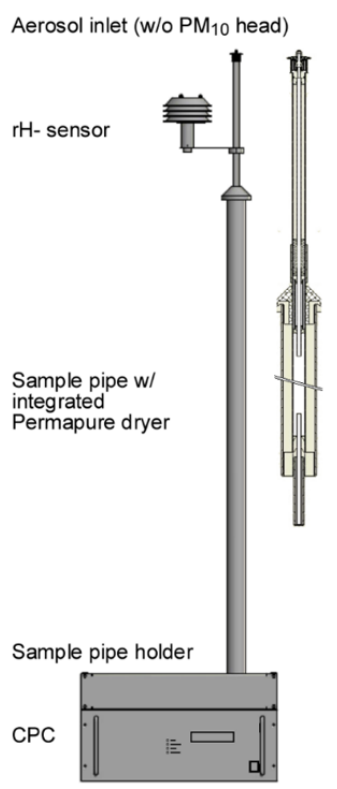

\section{Figure 8:}

Schematic representation of the core unit consisting of CPC5421 with attached dryer stage. As other environmental measurement devices in the container are also fed with outside

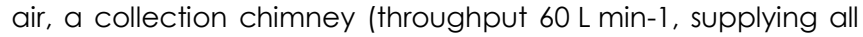
instruments) was installed on the container. An enlarged section of the inlet with permapure dryer is depicted to the right of the entire unit. 
The relative humidity $(\mathrm{rH})$ and outdoor temperature $(\mathrm{T})$ are recorded by appropriate $\mathrm{rH}$ - and T-sensors. Sample air entering the measuring unit via the sample inlet (see Figure 8) is routed past a permapure dryer (consisting of a Nafion-membrane) straight towards the CPC. Once a threshold $\mathrm{rH}$-value of $55 \%$ is exceeded, the drying stage is activated autonomously. Once it drops below $55 \%$, the dryer is deactivated. Aerosol drying is essential particularly during the warmer months of the year as the fairly cool conditions within the measurement unit would inevitably result in condensation, flooding the sampling line with significant amounts of water that could damage sensitive parts of the sampling equipment.

The main advantage of dehumidifying air with Nafion is that sample air is not heated. Thus, drying takes place at almost the same temperature as counting the aerosol particles, thus avoiding degassing of volatile organic carbons even before the measurement cell is reached. As outlined in the upper part of Figure 9, dried air flows in the opposite direction, on the outside of the Nafion-membrane, which separates it from the aerosol sample flow. Aerosol drying using a Nafion membrane is achieved by generating a pressure gradient across the membrane. This gradient is obtained by mixing $1.2 \mathrm{~L} \mathrm{~min}^{-1}$ of exhaust air from the system (sample out) with 1.8 L min-1 of room air (inside air); in a second step, it is filtered and sucked through a critical orifice (needle valve) via a vacuum pump. The counter-flow of this sleeve of clean, dry air assures that the removal of residual humidity from the sample air occurs steadily and at the same time avoids the accumulation of humidity along the Nafion-membrane. Nafion consists of a fluorocarbon backbone dotted with sulfonic-acid side chains that exhibit three distinct properties:

i) acts as acid catalyst due to the strongly acid properties of the sulfonic acid group;

ii) functions as an ion exchange resin when exposed to solutions;

iii) readily absorbs water, from the vapour phase; i.e. each sulfonic acid group will absorb up to 13 molecules of water. The sulfonic acid groups form ionic channels through the bulk hydrophobic polymer enabling water to be readily transported through these channels.

Once the water has passed the membrane, a vacuum pump routes the moisture to a condensation drain, where it is released to the exhaust outlet. 
Vorage et al

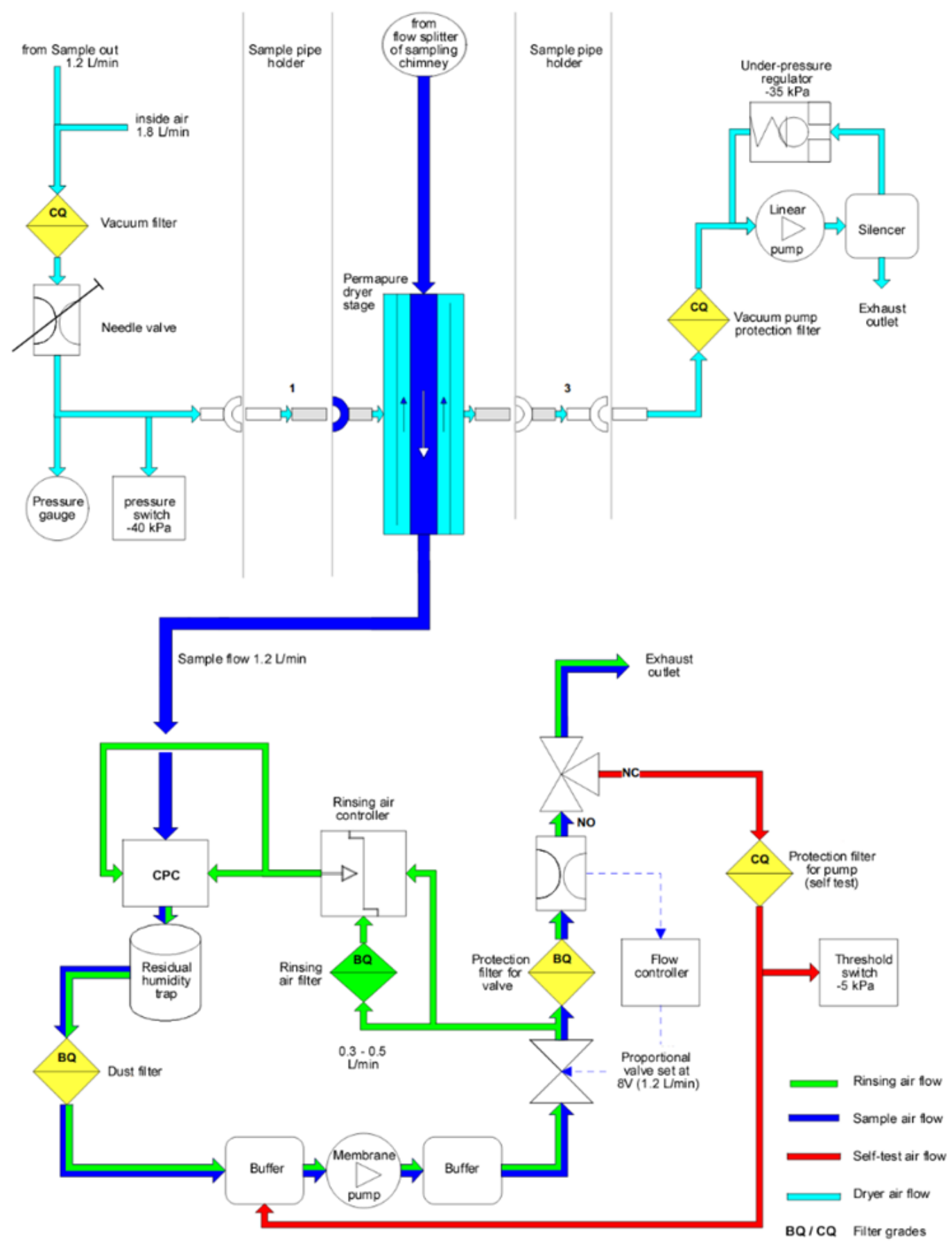

Figure 9: Block diagram of the principal components of the sampling unit consisting of Nafion-dryer stage and CPC detection unit. 
The dried sampling air is then routed towards the actual measurement unit (lower part of Figure 9), where various auxillary sampling lines are embedded. These are necessary to flush the system with clean air, enable repetitive self-test modes along with zero-check count modes at regular intervals, and continously monitor the flow through the pipeline. These additional modes are necessary in order to maintain a calibrated count mode throughout the entire operation of the system. Once these control parameters are within a given tolerance window, the dried aerosol is routed into the CPC, where the actual counting takes place.

\section{Condensation Particle Counter (CPC)}

The working principle of a CPC (Grimm, 2020a; Grimm, 2020b; Grimm, 2020c) is basically identical to an optical particle counter (OPC). However, owing to the fact that the optical detection uses a laser operated in the visible size range, this would imply that only particles $>250 \mathrm{~nm}$ would be detectable. Sensing particles as small as $5 \mathrm{~nm}$ requires an additional pretreatment of the coarse aerosol prior to counting. As shown in Figure 10, this can be achieved via a condensation technique using an alcohol that works with both hydrophilic and hydrophobic aerosols.

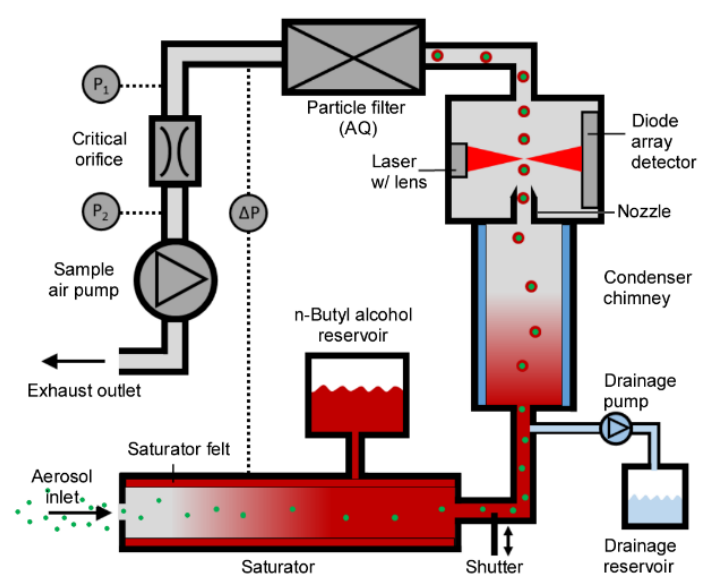

Figure 10: Basic functional units of the CPC-5421 unit.

The sample air flow is first routed through a saturation chamber. It consists of a n-butylalcohol-saturated felt that is heated to a constant $36^{\circ} \mathrm{C}$. This temperature assures saturated conditions within the saturator stage of the CPC, where both aerosol and alcohol vapour can mix properly. To induce particle growth via heterogeneous condensation, the aerosol-alcohol vapour is chilled down to $10^{\circ} \mathrm{C}$ in the condenser stage of the CPC. Rapid cooling (maintained via the constant aerosol flow of $1.2 \mathrm{~L} \mathrm{~min}^{-1}$ ) assures that alcohol condenses onto the nm-sized aerosol fraction within the condenser's chimney, generating $\mu \mathrm{m}$-sized particles that can be easily detected within the optical particle counter unit. To do this, the enlarged aerosol is routed through a nozzle that generates a train of aerosol particles, which feeds directly into the downstream OPC-unit (see below). 


\section{Principle of Optical Particle Counting (OPC) within the CPC}

A tiny aerosol stream leaves the condensor stage via a stainless-steel tube $\left(\mathrm{d}_{\mathrm{i}}=3 \mathrm{~mm}\right)$ and interacts with an orthogonally positioned laser beam (see Figure 11). Since the laser is orthogonally aligned, the detector array will not be blinded by the light coming from the laser beam. Only aerosol-induced scattered light will reach the detector. In order to enhance the detection threshold, a mirror is used to increase yield. The count rate is derived from the number of particles and the volume flow rate.

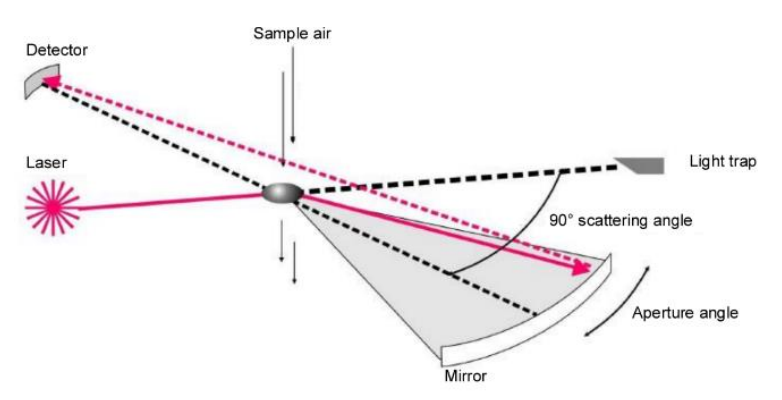

Figure 11: Particle counting via scattered laser light

Depending on aerosol concentration, two counting modes are used in the CPCs: the single particle count mode, which detects single scattered light pulses, is predominant for low particle concentrations $\left(<1.5 \cdot 10^{5} \mathrm{~cm}^{-3}\right)$. The photometric mode, on the other hand, detects an aerosol cloud and becomes the dominant counting mode at high aerosol concentrations $\left(>1.5 \cdot 10^{5} \mathrm{~cm}^{-3}\right)$. The single counting mode represents an absolute count mode, whereas the photometric mode is a nephelometer-like absorption mode that requires empirical calibration. There is a transitional regime close to the switching point in which both modes are active and the particle concentration is calculated based on both modes depending on their proximity to the switching point.

\section{Acknowledgements}

We greatly thank Josef Schmitzberger (Federal State of Salzburg) who operated the measurement container, and Alexander Hubmer (University of Salzburg) for his technical expertise. We would also like to express our thanks to Claudia Typelt (Salzburg Airport) for providing flight routes based on Noise Desk ${ }^{\circledR}$ data. 


\section{References}

Agrawal SK, Daiutolo H (1985). Modified reflex-percussive Grooves for Runways. Transportation Research Record, 1048, 43-49

AVIATOR (2020). Assessing Aviation Emission Impact on Local Air quality at Airports. Available online (accessed Jan'20): https://trimis.ec.europa.eu/project/assessing-aviation-emission-impactlocal-air-quality-airports-towards-regulation

Azarmi F, Kumar P (2016). Ambient exposure to coarse and fine particle emissions from building demolition. Atmospheric Environment, 137, 62-79.

Azarmi F, Kumar P, Mulheron M (2014). The exposure to coarse, fine and ultrafine particle emissions from concrete mixing, drilling and cutting activities. Journal of Hazardous Materials, 279. 268-279.

Bakand S, Hayes A, Dechsakulthorn F (2012). Nanoparticles: a review of particle toxicology following inhalation exposure. Inhalation Toxicology, 24, 125-135.

Bové H, Bongaerts E, Slenders E, Bijnens E, Saenen N, Gyselaers W, Van Eycken P, Plusquin M, Roeffaers M, Ameloot M. Nawrot T. (2019). Ambient black carbon particles reach the fetal side of human placenta. Nature Communications, 10. 1-7.

Bujak-Pietrek S, Mikołajczyk U (2019). Emission of nanometer size particles during selected processes with construction materials. Medycyna Pracy, 70(1), 68-88.

Cassee FR, Héroux ME, Gerlofs-Nijland ME, Kelly FJ (2013). Particulate matter beyond mass: recent health evidence on the role of fractions, chemical constituents and sources of emission. Inhalation Toxicology, 25(14), 802-812.

EuroLex (2019). European Union Law - measurement of emissions during cold engine start periods and use of portable emissions measurement systems (PEMS) to measure particle numbers, with respect to heavy duty vehicles; Document 32019R1939. Available online (accessed January 2020): https://eur-lex.europa.eu/eli/reg/2019/1939/oj

Gatti A. Montanari S. (2015). Case Studies in Nano-Toxicology and Particle Toxicology. Elsevier; https://doi.org/10.1016/C2013-0-18692-8

Grimm (2020a). Model 5421 - The 19" rack-based condensation particle counter. Available online (accessed October 2020): https://www.grimm-aerosol.com/products-en/nano-particle-measurement/cpc/5421/

Grimm (2020b). Condensation particle counters for nanoparticles. Available online (accessed October 2020):

https://www.grimm-aerosol.com/fileadmin/files/grimm-

aerosol/3\%20Products/Nano\%20Particle\%20Measurement/CPC/5412/Product\%20PDFs/CPC s.pdf

Grimm (2020c). The catalog 2020. Available online (accessed October 2020):

https://www.grimm-aerosol.com/fileadmin/files/grimm-

aerosol/General_Downloads/The_Catalog_2020_web_version.pdf

Herndon SC, Jayne JT, Lobo P, Onasch TB, Fleming G, Hagen DE, Whitefield PD, Miake-Lye RC (2008). Commercial Aircraft Engine Emissions Characterization of in Use Aircraft at Hartsfield Jackson Atlanta International Airport. Environmental Science Technology, 42, 1877-1883.

Herner J, Robertson W, Ayala A (2007). Investigation of Ultrafine Particle Number Measurements from a Clean Diesel Truck Using the European PMP Protocol. SAE Technical Paper, 2007-01-1114.

Hoek G, Boogaard H, Knol A, de Hartog J, Slottje P, Ayres JG, Borm P, Brunekreef B, Donaldson K, Forastiere F, Holgate S, Kreyling WG, Nemery B, Pekkanen J, Stone V, Wichmann HE, van der Sluijs J (2010). Concentration response functions for ultrafine particles and all-cause mortality and hospital admissions: results of a European expert panel elicitation. Environmental Science,Technology, 44, 476-482. 
Jabbour N, Jayaratne ER, Johnson GR, Alroe J, Uhde E, Salthammer T, Cravigan L, Faghihi EM, Kumar P, Morawska L (2017). A mechanism for the production of ultrafine particles from concrete fracture. Environmental Pollution, 222, 175-181.

Janhäll S, Olofson FG, Andersson PU, Pettersson JBC, Hallquist M (2006). Evolution of the urban aerosol during winter temperature inversion episodes. Atmospheric Environment, 40(28), 53555366.

Kinsey JS (2009). Characterization of emissions from commercial aircraft engines during the aircraft particle emissions experiment (APEX) 1 to 3, EPA 600/R 09/130. Available online (accessed January 2020): https:// nepis.epa.gov/Exe/ZyPURL.cgi?Dockey=P1005KRK.txt

Kleinman MT, Araujo JA, Nel A, Sioutas C, Campbell A, Cong PQ, Li H, Bondy SC (2008). Inhaled ultrafine particulate matter affects CNS inflammatory processes and may act via MAP kinase signaling pathways. Toxicology Letters, 178(2), 127-130.

Kranabetter A (2019). Monatsbericht März 2019 des Landes Salzburg; available online (accessed April 2020) https://www.salzburg.gv.at/themen/umwelt/luft/luftberichte

Kreyling W, Hirn A, Schleh C (2010). Nanoparticles in the lung. Nature Biotechnology, 28, 1275-1276.

Kreyling W, Semmler-Behnke M, Takenaka S, Moller W (2013). Differences in the biokinetics of inhaled nano-versus micrometersized particles. Accounts of Chemical Research, 46, 714-722

Kumar P, Mulheron M, Som C (2012). Release of airborne ultrafine particles from the three simulated building activities. Journal of Nanoparticle Research 14(771), 1-18.

Loane C, Pilinis C, Lekkas TD, Politis M (2013). Ambient particulate matter and its potential neurological consequences. Review of Neuroscience, 24(3), 323-335.

Lobo P, Hagen DE, Whitefield PD (2012). Measurement and analysis of aircraft engine PM emissions downwind of an active runway at the Oakland International Airport. Atmospheric Environment, 61, 114-123.

Lobo P, Hagen DE, Whitefield PD, Raper D (2015). PM emissions measurements of in- Service commercial aircraft engines during the Delta Atlanta Hartsfield Study. Atmospheric Environment, 104, 237-245.

Lu S, Zhang W, Zhang R, Liu P, Wang Q, Shang Y, Wu M, Donaldson K, Wang Q (2015). Comparison of cellular toxicity caused by ambient ultrafine particles and engineered metal oxide nanoparticles. Particle and Fibre Toxicology, 12(5), 1-12.

Mazaheri M, Bostrom TE, Johnson GR, Morawska L (2013). Composition and morphology of particle emissions from in use aircraft during takeoff and landing. Environmental Science Technolology, 47, 5235-5242.

Miller MR, Raftis JB, Langrish JP, McLean SG, Samutrtai P, Connell SP, Wilson S, Vesey AT, Fokkens PHB, Boere AJF, Krystek P, Campbell CJ, Hadoke PWF, Donaldson K, Cassee FR, Newby DE, Duffin R, Mills NL (2017). Inhaled Nanoparticles Accumulate at Sites of Vascular Disease, ACS Nano, 11(5), 4542-4552.

Møller K, Thygesen L, Schipperijn J, Loft S, Bonde J, Mikkelsen S, Brauer C (2014). Occupational Exposure to Ultrafine Particles among Airport Employees Combining Personal Monitoring and Global Positioning System. PLoS ONE, 9:9, e106671.

Moore R, Thornhill K, Anderson E (2017). Biofuel blending reduces particle emissions from aircraft engines at cruise conditions. Nature, 543, 411-415.

Morawska L, Jamriska M, Guo H, Jayaratne ER, Cao M, Summerville S (2009). Variation in indoor particle number and PM2.5 concentrations in a radio station surrounded by busy roads before and after an upgrade of the HVAC system. Building and Environment, 44, 76-84.

Morawska L, Ristovski Z, Jayaratne ER, Keogh DU, Ling X (2008). Ambient nano and ultrafine particles from motor vehicle emissions: Characteristics, ambient processing and implications on human exposure. Atmospheric Environment, 42, 8113-8148.

Oberdörster G, Oberdörster E, Oberdörster J (2005). Nanotoxicology: an emerging discipline evolving from studies of ultrafine particles. Environmental Health Perspectives, 113, 823-839. 
Oberdörster G, Sharp Z, Atudorei V, Elder A, Gelein R, Kreyling WG, Cox C (2004). Translocation of inhaled ultrafine particles to the brain. Inhalation Toxicology, 16(6-7), 437-445.

Peters J, Berghmans P, Van Laer J, Frijns E (2016). 'UFP en BC metingen rondom de luchthaven van Zaventem', commissioned by Vlaamse Milieumaatschappij (VMM) and Bouwwerk Informatie Management (BIM). 2016/MRG/R/0493. Available online (accessed January 2020): https://bifluglaerm-raunheim.de/doku/2016-05_VITO_UFP-measurements_Brussels-Zaventem_englishsummary.pdf

Press-Kristensen K, Brogaard L, Jacobsen JA, Ellerman T (2012). Air Pollution in Airports: Ultrafine particles, solutions and successful cooperation, 1st ed, Danish Ecocouncil. Available online (accessed January 2020):

https://aragge.ch/wp-content/uploads/2018/04/DK_Ecocouncil_20120328_Air-Pollution-inAirports_en.pdf

Quang TN, He C, Morawska L, Knibbs LD (2013). Influence of ventilation and filtration on indoor particle concentrations in urban office buildings. Atmospheric Environment, 79, 41-52.

Ren J, Liu J, Li F, Cao X, Ren S, Xu B, Zhu Y (2016). A study of ambient fine particles at Tianjin International Airport, China', Science of the Total Environment, 556, 126-135.

Salzburg Airport (2019). Generalsanierung Piste von 24.04.2019 - 28.05.2019'. Available online (accessed September 2019) https://www.salzburg-airport.com/fileadmin/user_upload/pdf/Leporello_PISA_2019.pdf

Salzburg Airport (2020). Statische Daten. Available online (accessed January 2020) https://www.salzburg-airport.com/unternehmen-airport/ueber-uns/statistiken/

Seinfeld J, Pandis S (2016). Chapter 8: Properties of the Atmospheric Aerosol. In: Atmospheric Chemistry and Physics - From Air Pollution to Climate Change, 3rd ed. John Wiley \& Sons. Hoboken (NJ) USA. ISBN: 978-1-118-94740-1.

Stafoggia M, Cattani G, Forastiere F, di Bucchianico ADM, Gaetaand A, Ancona C (2016). Particle number concentrations near the Rome-Ciampino city airport. Atmospheric Environment, 147, 294273.

Stephens B, Siegel JA (2013). Ultrafine particle removal by residential heating, ventilating, and airconditioning filters. Indoor Air, 23(6): 488-497.

Timko MT, Fortner E, Franklin J, Yu Z, Wong HW, Onasch TB, Miake-Lye RC, Herndon SC (2013). Atmospheric Measurements of the Physical Evolution of Aircraft Exhaust Plumes. Environmental Science and Technology, 47, 3513-3520.

Ulvestad B, Randem BG, Hetland S, Sigurdardottir G, Johannessen E, Lyberg T (2007). Exposure, lung function decline and systemic inflammatory response in asphalt workers. Scandinavian Journal of Work, Environment \& Health, 33(2), 114-121.

Vorage M, Madl P, Hubmer A, Lettner H (2019). Aerosols at Salzburg Airport: Long-term measurements of ultrafine particles at two locations along the runway / Aerosole am Salzburger Flughafen: Langzeit - messungen von ultrafeinen Partikeln an zwei Messstellen neben der Rollbahn. Gefahrstoffe Reinhaltung der Luft, 79. 227-234.

Wang M, Dewil R, Maniatis K, Wheeldon J, Tan T, Baeyens J, Fang Y (2019). Biomass-derived aviation fuels: Challenges and perspective. Progress in Energy and Combustion Science, 74, 31-49.

Yacobi N, Fazllolahi F, Kim Y, Sipos A, Borok Z, Kim K, Crandall E (2011). Nanomaterial interactions with and trafficking across the lung alveolar epithelial barrier: implications for health effects of airpollution particles. Air Quality, Atmosphere and Health, 4, 65-78.

Zhu Y, Fanning E, Yu RC, Zhang Q, Froines JR (2011). Aircraft emissions and local air quality impacts from takeoff activities at a large International Airport. Atmospheric Environment, 45, 6526-6533.

Zhu Y, Hinds WC, Kim S, Sioutas C (2002). Concentration and size distribution of ultrafine particles near a major highway. Journal of the Air and Waste Management Association, 52, 1032-1042. 